\title{
The phenolic compounds of ethanolic extract of date seed (Phoenix dactylifera 1.) exert hepatoprotective activity on rat induced carragenan
}

\author{
Warsinah ${ }^{1 *}$, Esti Dyah Utami1 ${ }^{1}$ Hanif Nasiatul Baroroh ${ }^{1}$ \\ ${ }^{1}$ Departement of Pharmacy, Faculty of Health Sciences, Jenderal Soedirman University, Purwokerto. Indonesia \\ ${ }^{*}$ Correspondent author: warsinahapt@gmail.com
}

\begin{abstract}
Background: Hepatotoxic effects can occur with the use of toxic drugs or standard doses, but in the long term or chronic therapy. In addition to the drugs, carrageenan also causes hepatotoxic after 12 hours of induction intraperitoneally. The effect liver cell repair is highly related to the antioxidant activity of phenolic compounds in date seeds.

Objective: The present study determined the total phenolic levels and hepatoprotective activity of ethanol extracts of date palm seeds (EEBK) in carrageenan-induced rats.

Method: Determination of total phenolics in palm ethanol extract samples was carried out with the FolinCiocalteu reagent. This study was the pre and post-test control group design. Examination of SGOT and SGPT levels was performed by the kinetic method based on IFCC. Data was analyzed using paired t-test and ANOVA test.

Results: The total phenolic content of the ethanol extract of date seeds of Deglet Noor variety was 8.521\% GAE. The ethanol extract of date seed (EEBK) with the dose of $150 \mathrm{mg} / \mathrm{kg}$ BW showed the highest reduction in SGOT levels (34.80 U / L). The highest average decrease in SGPT levels occurred at a therapeutic dose of $300 \mathrm{mg} / \mathrm{kg}$ BW was $16.20 \mathrm{U} / \mathrm{L}$ compared to doses of 150 and $600 \mathrm{mg} / \mathrm{kg}$ bb (11.60 and $15.60 \mathrm{U} / \mathrm{L}$ respectively).

Conclusion: The ethanol extract of date seed (EEBK) with the doses of 150, 300, and $600 \mathrm{mg} / \mathrm{kg} \mathrm{BW}$ had hepatoprotective activity in carrageenan-induced rats as observed from a significant decreased in SGOT and SGPT levels $(\mathrm{p}<0.05)$.

Key word: Date seed, phenolic total, extract, SGPT, SGOT
\end{abstract}

\section{Introduction}

The liver as the body's metabolic center can be damaged by drugs, because drug compounds (partial or full metabolism) are eliminated through the liver (Loho \& Hasan, 2014). Drug use may causes hepatotoxicity or drug-induced liver injury (DILI) (Sonderup, 2011) which is increasing every year on its prevalence. The use of DILI in Dr. Hospital. M. Djamil Padang has reached $47 \%$ with all $100 \%$ of subjective and objective symptoms of hepatotoxicity (Julita, 2012). Hepatotoxic effects can occur with the use of toxic drugs or standard doses, but in the long term or chronic therapy. Previous study reported that carrageenan is one of compound that has hepatotoxicity after 12 hours of intraperitoneal administration (Fowler et al., 1977; Mansouri et al., 2015). The prevalence of the hepatotoxicity can be decreased by hepatoprotective agent. One of the natural ingredients can be developed as hepatoprotective is date palm seeds (Phoenix dactylifera L) since it contains phenolic compounds with high antioxidant activity. The ethanol extract of date 
palm seed contains the highest phenolic compounds (4.84\%), compared to acetone extract (4.30\%), methanol extract (4.00\%), and water extract (0.875\%) (Ammar \& Habiba, 2010). Phenolic compounds that detected in date palm seeds including catechins, quercetin, luteolin, procyanidins, epicatechins, and proanthocyanidins (Hammouda et al., 2013). Moreover, luteolin, quercetin, and catechins showed a protective effect on hepatocyte cells (Añón et al., 1992). Another study found that suspension in distilled water could improve liver lesions in the form of vacuolization and fibroblast proliferation in the rat liver (Abdelaziz \& Ali, 2014). Based on that information, it is necessary to evaluate the determination of total phenolic levels and hepatoprotective activity of ethanol extract of date palm seeds in carrageenan-induced rats evaluated from the decreasing level of SGOT and SGPT.

\section{Methods}

\subsection{Materials}

Ethanol 96\%, Na-CMC, carrageenan, Folin-Ciocalteu reagent, Gallic acid and $\mathrm{Na}_{2} \mathrm{CO}_{3}$ (SigmaAldrich Pte. Ltd., Singapore), NaCl 0,9\% (Otsuka), BR2, diagnostic reagent of SGOT dan SGPT (Diasys), Date seed powder (Deglet Noor).

\subsection{Preparation of date seed ethanol extract}

Five hundred grams of date seed powder was put in a macerator and added with 2 liters of ethanol, then soaked for 24 hours and filtered. The maceration process was repeated up to $3 \times 24$ hours. The filtrate was evaporated using a vacuum evaporator until produced the ethanol extract of date seed (EEBK).

\subsection{Determination of total phenolic content}

The ethanol extract of date seeds $(0.5 \mathrm{~mL})$ was added to $2.5 \mathrm{ml}$ of $10 \%$ Folin-Ciocalteu reagent in a test tube, kept in dark room for 5 minutes, and then added by $2 \mathrm{~mL}$ of $7.5 \% \mathrm{Na}_{2} \mathrm{CO}_{3}$, stored in the dark for 3 hours. The absorbance of the extract was detected using spectrophotometer at the maximum wavelength obtained from a standard solution of gallic acid, which was $759.70 \mathrm{~nm}$. Standard curves for gallic acid as a standard solution were prepared using similar procedure with the concentrations of 30, 32, 40, 60 and $80 \mathrm{ppm}$.

\subsection{Hepatoprotective activity}

The hepatoprotective activity was evaluated using pretest and posttest control group design. Twenty-five males Wistar rats aged 2-3 months and approximately 180-200-gram weight was divided in to five groups: normal group, the negative control and three treatment groups. The normal group was only given standard feed without any treatment. The negative control and the 
treatment groups were induced by $1 \%$ carrageenan $2.5 \mathrm{ml} / 100$ gram (i.p.) on day 1, 4, 8 and 11 . Furthermore, the negative control was treated by vehicle Na-CMC solvent while the treatment group was administered by ethanol extract of date palm seeds with graded dose of 150, 300, and $600 \mathrm{mg} / \mathrm{kg}$ BW every day for 14 days, orally. Blood serum in normal, negative control, and treatment groups were collected at 12 hours post carrageenan induction (pretest) and on the day 15, at the end of the study, to determine the levels of both SGOT and SGPT. The levels of SGOT and SGPT was analyzed by kinetic method based on the International Federation of Clinical Chemistry (IFCC) using the DiaSys diagnostic kit. On the day 15, rats were sacrificed, and liver were isolated to be prepared for histopathological preparation with hematoxylin-eosin (HE) staining. The observations of liver changes (degeneration and necrosis) were investigated by a light microscope with $10 \times 40$ magnification, five fields of view.

\subsubsection{Data analysis}

Data were analyzed by SPSS 17 for windows with homogeneity test and Shapiro-Wilk for the normality test. Hypothesis testing employed paired t-test and ANOVA.

\section{Result and discussion}

The total phenolic content of the ethanol extract of the date seeds was 8.521\% GAE which was higher than the ethanol extract of other varieties of date palm seeds such as Rashodia (4.35\%), Nabtet-Ali (4.84\%), Sukkari (4.76\%), Sakai (4.76\%) and Rothana (4.94\%) (Ammar \& Habiba, 2010). The differences of total phenolic levels in date seeds can occur because the dates come from different varieties. The other factors including genetics, plant sources, climatic conditions, and storage conditions may influence the total of phenolic levels (Gorinstein et al., 2009). In addition, the production of phenolic compounds as secondary metabolite are strongly correlated to the presence of micro-organisms and insects, stress by UV radiation, exposure to the heavy metals, and the use of pesticides (Wang et al., 2009).

The pretest SGOT and SGPT levels was analyzed using ANOVA followed by a post hoc test using LSD. It resulted the control and treatments were significantly $(\mathrm{p}<0.05)$ different compared to the normal group (Table 1 and Table 2). The increasing of SGOT and the SGPT levels induced by carrageenan become one of the hepatotoxicity parameters. Carrageenan triggers the release of several cytokines such as TNF $\alpha$ and IL1 $\beta$ (Nacife et al., 2004). TNF $\alpha$ triggers the release of IL1 $\beta$ and cytokine-induced neutrophil chemo attractant 1 which responsible for the stimulation of PG synthesis by COX-2. In addition, TNF $\alpha$ induces NO synthesis by activating iNOS and augmenting neutrophil responses to inflammatory stimuli in the liver (Cunha et al., 2005). 
The inflammation of the liver subsequent oxidative stress induction mediates the changes in SGOT or SGPT level on pre and post induction. The groups that experienced a decrease in SGOT and SGPT level were the normal and the treatment group. There was no decreasing effect of both SGOT and SGPT level in negative control group. In fact, the post-test result was higher than the pretest and displayed significant differences based on paired t-test analysis $(\mathrm{p}<0.05)$ (Table1 and Table 2). It conferred that Na-CMC solvent for negative control group had no hepatoprotective effect. The levels of SGOT and SGPT figures out the severity of hepatotoxicity. In the normal group, although there was a decreasing of both SGOT and SGPT level, yet not significant according to the paired ttest ( $p>0.05$ ). Meanwhile, a significant decrease found in treatment of date seed doses of 150, 300, and $600 \mathrm{mg} / \mathrm{kg} \mathrm{BW}(\mathrm{p}<0.05)$. The extract possessed hepatoprotective effect since there was decreasing of post-test of SGOT and SGPT levels compared to pre-test that significantly difference for all doses of ethanol extract of date seeds $(\mathrm{p}<0.05)$ against negative control group. The average of declining in SGOT level for the treatments group at the dose of 150, 300, and $600 \mathrm{mg} / \mathrm{kg}$ BW was $43,25.8$ and 34.8 respectively that showed significant differences to negative control. Moreover, the similar result for SGPT level that significantly different for all the treatment doses compare to the negative exhibit decreasing level of $11.60,16.20$, and 15.60 for doses $150,300,600 \mathrm{mg} / \mathrm{kg}$ BW consecutively. However, the ANOVA test resulted that there were no significant differences on SGOT and SGPT ( $>0.05)$ for all treatment group. Hence, the variation of ethanol extract of dates palm seeds doses did not interfere its anti-hepatotoxic activity based on the parameters of SGOT and SGPT (Table 1 and Table 2).

Table1. The SGOT levels of dates palm seed ethanolic extract

\begin{tabular}{|c|c|c|c|}
\hline Group & $\begin{array}{c}\text { SGOT pre-test } \\
(\mathrm{U} / \mathrm{L})\end{array}$ & $\begin{array}{c}\text { SGOT post-test } \\
(\mathrm{U} / \mathrm{L})\end{array}$ & $\begin{array}{l}\text { Decreasing of } \\
\text { SGOT level }\end{array}$ \\
\hline Normal & $82.00 \pm 8.22$ & $79.00 \pm 6.21$ & $3.00 \pm 8.57$ \\
\hline Negative & $149.00 \pm 29.24 \infty$ & $468.00 \pm 61.17$ & $-319.00 \pm 54.14$ \\
\hline EEBK 150 & $137.80 \pm 18.36 \infty$ & $94.80 \pm 19.730$ & $43.00 \pm 4.69^{*}$ \\
\hline EEBK 300 & $142.00 \pm 19.08 \infty 0$ & $116.20 \pm 21.820$ & $25.80 \pm 4.82^{*}$ \\
\hline EEBK 600 & $149.80 \pm 14.01 \infty$ & $115.00 \pm 16.690$ & $34.80 \pm 11.32 *$ \\
\hline
\end{tabular}

The decreasing in SGOT and SGPT levels in the ethanol extract of date palm seeds arise due to the high content of phenolic compounds in the ethanol extract of date palm seeds (Ammar \& Habiba, 2010). Flavonoids and phenolic inhibit both cytochrome P450 and lipid peroxidation by exerting a membrane-stabilizing action (Middleton et al., 2000), thereby supporting liver regeneration (Kowalska et al., 1990). The SGOT and SGPT is associated with the SOD and GST. The cytokine NF- $\kappa$ B activity was inhibited by GST (Muriel, 2017). Date seed extract decrease NF- $\kappa$ B 
activation and suppress the expression of COX-2 (Attia et al., 2016). Liver inflammation processes including matrix swelling, fibrosis progression, and hepatocellular carcinoma development. The pro-inflammatory pathway was a potential strategy to prevent inflammatory liver injury and fibrogenesis (Planagumà et al., 2005; Yamamoto et al., 2003). Date seed extract maintains the activity of the antioxidant enzyme HO-1 in the liver, which is a potential mechanism on preventing the expression of NF-אB in fibrotic liver tissue (Attia et al., 2016). Research by Xue et al. (2007) showed that high levels of HO-1 expression were decreased NF- $\kappa$ B expression to reduce the inflammatory reaction at 6 hours after reperfusion in the liver of cirrhotic mice.

Table 2. The SGPT levels of dates palm seed ethanolic extract

\begin{tabular}{|c|c|c|c|}
\hline Group & $\begin{array}{c}\text { SGPT pre-test } \\
\text { (U/L) }\end{array}$ & $\begin{array}{c}\text { SGPT post-test } \\
(\mathrm{U} / \mathrm{L})\end{array}$ & $\begin{array}{c}\text { Decreasing } \\
\text { of SGPT level }\end{array}$ \\
\hline Normal & $27.20 \pm 6.38$ & $25.20 \pm 6.02$ & $2.00 \pm 6.82$ \\
\hline Negative & $65.80 \pm 23.96^{\circ}$ & $172.80 \pm 28.28 \bullet$ & $-107.00 \pm 16.17$ \\
\hline EEBK 150 & $73.40 \pm 7.16^{\circ}$ & $61.80 \pm 7.43 \bullet$ & $11.60 \pm 5.32^{*}$ \\
\hline EEBK 300 & $72.80 \pm 12.75^{\circ}$ & $56.60 \pm 11.72 \bullet$ & $16.20 \pm 2.92^{*}$ \\
\hline EEBK 600 & $70.20 \pm 14.48^{\circ}$ & $54.60 \pm 15.88 \bullet$ & $15.60 \pm 2.97^{*}$ \\
\hline
\end{tabular}

In this study, there were no animal studies that experienced death or toxicity symptoms. The results of liver histopathology represent on Figure 1 for each test group. Macroscopic observations in the normal, negative control, and Date seed extract treatment group showed different colors of the liver. The normal as well as dates seed extract group was brownish red, while the negative control group was brown (figure 1). The normal liver has a red-brown color due to the flow of blood that enters the liver (Westbrook et al., 2016). Changes in color gradation as the dose increases is namely the darker color gradation.

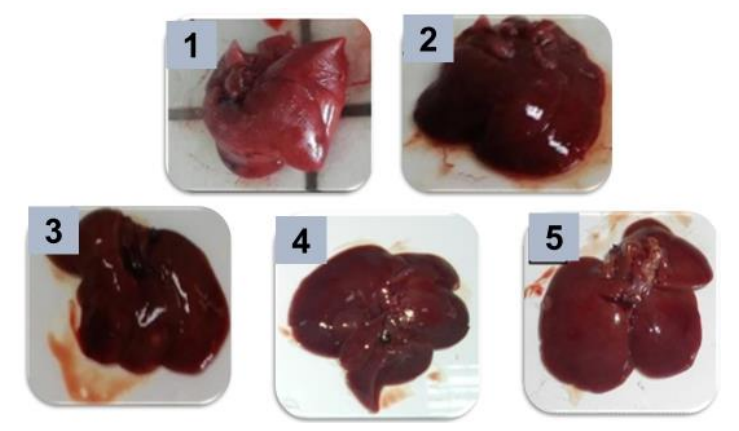

Figure 1. Morphological profile of rat liver

Note: 1. Normal, 2. Negative Control, 3. Treatment with a dose of $150 \mathrm{mg} / \mathrm{BW}, 4$. Treatment with a dose of $300 \mathrm{mg} / \mathrm{BW}$ and 5. Treatment with a dose of $600 \mathrm{mg} / \mathrm{BW}$

Contrary to the normal features of macroscopic observation, the microscopic investigation showed hydropic degeneration, fatty degeneration, and necrosis on all groups (Figure 2). 
Furthermore, it was also detected varying degrees of damage of the hepatocyte. Normally, the hepatocytes are polygonal in shape and have a homogeneous red cytoplasm (Muriel, 2017). The parenchymatous degeneration cytoplasm is the mildest and reversible degeneration that characterized by unclear boundary between the cell nucleus and cytoplasm. The degeneration was due to oxidation interferences leading to the accumulation of protein deposits in the cytoplasm. Persistent parenchymatous degeneration may induce the hydropic degeneration. Hepatocyte that undergoes hydrophilic degeneration is swelling and water filled vacuole appearing in the cytoplasm. The hepatocyte damage continues tearing the plasma membrane and nuclear resulting necrosis. It occurs when the reactive chemical metabolites bind to hepatocyte ultimately on nucleophilic proteins. Metabolites with free chains bind covalently to proteins and unsaturated fatty acids of cell membranes, causing lipid peroxidation and membrane damage which particularly yielding in hepatocyte death (Amalina, 2009). The damage of hepatocyte was scored and analyzed using one-way ANOVA that showed not significantly differences among groups (Figure 3).
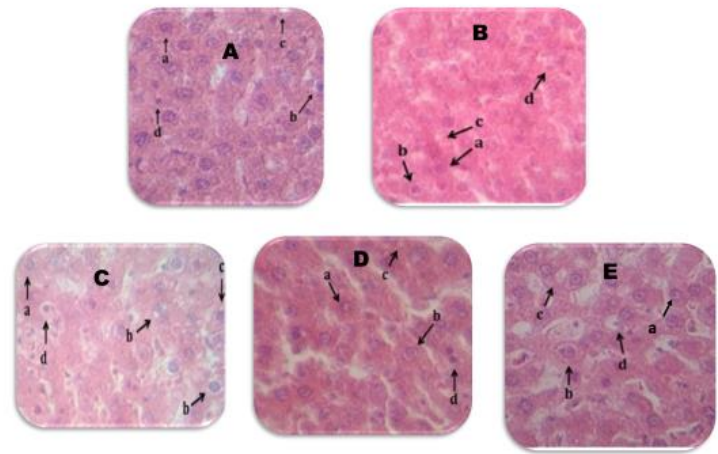

Figure 2. Histopathological profile of the liver

A. Normal control; B. Negative control; C. EEBK 150 treatment group; D. EEBK treatment group 300; E. EEBK treatment group 600; a. normal hepatocytes, b. hydropic degeneration, c. fatty degeneration, d. necrosis; 400x magnification, HE stains

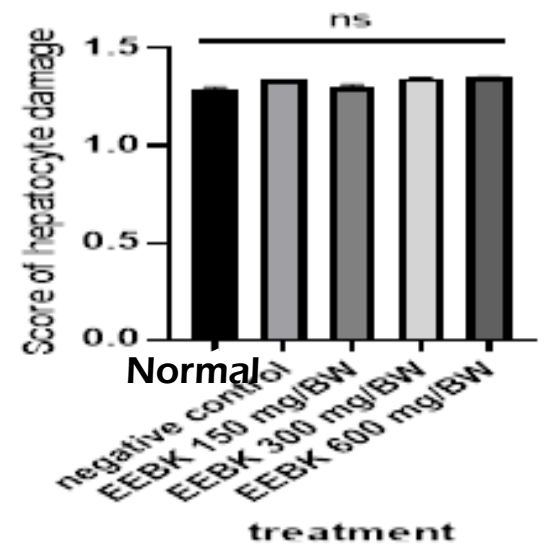

Figure 3. Score of hepatocyte damage 
The administration of various doses of ethanol extract of dates seed did not show any significant changes in the microscopic profile of the liver of experimental animals despite the fact lowering the hepatic enzyme parameters. Hepatocyte damage was found in all group that may possibly be due to the influence of unhygienic food or external factors such as the environment, causing health problems for rats.

\section{Conclusion}

In conclusion, the total phenolic content of the ethanol extract of the Deglet Noor dates palm seeds was 8,521\% GAE. Dates seed ethanol extract doses of 150, 300, and $600 \mathrm{mg} / \mathrm{kg}$ BW possessed hepatoprotective effect on carrageenan-induced rats by lowering both SGOT and SGPT level. There was no significant difference ( $p>0.05$ ) between the three variations of doses on its activity. Based on the liver histopathological features, the dates seed with the dose of $150 \mathrm{mg} / \mathrm{kg}$ BW was the most optimal dose reducing the risk of side effects and toxicity from the ethanol extract of date palm seeds.

\section{Acknowledgement}

The authors thank to the Rector of the Jenderal Soedirman University through the chairman of the LPPM for the funding support in this research on the institutional research scheme. On this occasion, the authors also would like to thank all those who have helped conducting this study.

\section{References}

Abdelaziz, D. H., \& Ali, S. A. (2014). The Protective Effect of Phoenix Dactylifera L. seeds Against CCl4-Induced Hepatotoxicity in Rats. J Ethnopharmacol, 155(1), 736-743. doi:10.1016/j.jep.2014.06.026

Amalina, N. (2009). Uji toksisitas akut ekstrak Valerian (Valeriana officinalis) terhadap hepar Mencit Balb/C (Bachelor). Universitas Diponegoro, Semarang.

Ammar, A. S., \& Habiba, R. A. (2010). Phenolic Content and Antioxidant Activity of Date Seeds. J Agric Vet Sci Qassim Univ 3, 3, 3-8.

Añón, M. T., Ubeda, A., \& Alcaraz, M. J. (1992). Protective Effects of Phenolic Compounds on CCl4-induced Toxicity in Isolated Rat Hepatocytes. Z Naturforsch C J Biosci, 47(3-4), 275-279. doi:10.1515/znc1992-3-417

Attia, H., Al-Rasheed, N., Mohamad, R., Al-Rasheed, N., \& Al-Amin, M. (2016). The Antifibrotic and Fibrolytic Properties of Date Fruit Extract Via Modulation of Genotoxicity, Tissue-inhibitor of Metalloproteinases and Nuclear Factor- Kappa B Pathway in A Rat Model of Hepatotoxicity. BMC Complement Altern Med, 16(1), 414. doi:10.1186/s12906-016-1388-2

Cunha, T. M., Verri, W. A., Jr., Silva, J. S., Poole, S., Cunha, F. Q., \& Ferreira, S. H. (2005). A Cascade of Cytokines Mediates Mechanical Inflammatory Hypernociception in Mice. Proc Natl Acad Sci U S A, 102(5), 17551760. doi:10.1073/pnas.0409225102

Fowler, E. F., Thomson, A. W., \& Horne, C. H. (1977). Alleviation of Carrageenan-Induced Hepatotoxicity and Acronecrosis by Aprotinin. Br J Exp Pathol, 58(3), 260-267.

Gorinstein, S., Haruenkit, R., Poovarodom, S., Park, Y. S., Vearasilp, S., Suhaj, M., Ham, K. S., Heo, B. G., Cho, J. Y., \& Jang, H. G. (2009). The Comparative Characteristics of Snake and Kiwi Fruits. Food Chem Toxicol, 47(8), 1884-1891. doi:10.1016/j.fct.2009.04.047

Seminar Nasional Asosiasi Perguruan Tinggi Farmasi Indonesia (APTFI) III-Tantangan Pandemik (covid-19) dalam pembelajaran dan penelitian kefarmasian 16-20 Agustus 2021 (Virtual Conference) 
Hammouda, H., Chérif, J. K., Trabelsi-Ayadi, M., Baron, A., \& Guyot, S. (2013). Detailed Polyphenol and Tannin Composition and Its Variability in Tunisian Dates (Phoenix dactylifera L.) at Different Maturity Stages. J Agric Food Chem, 61(13), 3252-3263. doi:10.1021/jf304614j

Julita, I. (2012). Aspek Farmakokinetik Klinik Beberapa Obat Berpotensi Hepatotoksik pada Pasien Rawat Inap di Bangsal Paru RSUP DR. M. Djamil Padang periode Oktober 2011-Januari 2012. Jurnal program master (S2) Unand, 3, 1-12.

Kowalska, M. T., Brandt, M. E., \& Puett, D. (1990). Inhibition of Cytochrome P-450 Aromatase Activity by Plant Extracts Planta medica 56, 675-675.

Loho, I. M., \& Hasan, I. (2014). Drug-Induced Liver Injury-Tantangan dalam Diagnosis. Cermin Dunia Kedokteran 41, 167-170.

Mansouri, M. T., Hemmati, A. A., Naghizadeh, B., Mard, S. A., Rezaie, A., \& Ghorbanzadeh, B. (2015). A Study of the Mechanisms Underlying the Anti-inflammatory Effect of Ellagic Acid in Carrageenan-induced paw Edema in Rats. Indian J Pharmacol, 47(3), 292-298. doi:10.4103/0253-7613.157127

Middleton, E., Jr., Kandaswami, C., \& Theoharides, T. C. (2000). The Effects of Plant Flavonoids on Mammalian Cells: Implications for Inflammation, Heart Disease, and Cancer. Pharmacol Rev, 52(4), 673-751.

Muriel, P. (2017). Liver Pathophysiology: Therapies and Antioxidants: Academic press.

Nacife, V., Soeiro, M., Gomes, R., D'Avila, H., Neto, H., \& Meirelles, M. (2004). Morphological and Biochemical Characterization of Macrophages Activated by Carrageenan and Lipopolysaccharide In Vivo. Cell structure and function, 29, 27-34. doi:10.1247/csf.29.27

Planagumà, A., Clària, J., Miquel, R., López-Parra, M., Titos, E., Masferrer, J. L., Arroyo, V., \& Rodé, J. (2005). The Selective Cyclooxygenase-2 Inhibitor SC-236 Reduces Liver Fibrosis by Mechanisms Involving NonParenchymal Cell Apoptosis and PPAR $\gamma$ Activation. The FASEB journal 19, 1120-1122. doi:https://doi.org/10.1096/fj.04-2753fje

Sonderup, M. W. (2011). Drug-Induced Liver Injuries. CME: Your SA Journal of CPD, 29, 244-246.

Wang, S., Chen, C.-T., \& Wang, C. (2009). The Influence of Light and Maturity on Fruit Quality and Flavonoid Content of Red Raspberries. Food Chemistry, 112, 676-684. doi:10.1016/j.foodchem.2008.06.032

Westbrook, R. H., Dusheiko, G., \& Williamson, C. (2016). Pregnancy and liver disease. J Hepatol, 64(4), 933945. doi:10.1016/j.jhep.2015.11.030

Xue, H., Guo, H., Li, Y. C., \& Hao, Z. M. (2007). Heme Oxygenase-1 Induction by Hemin Protects Liver Cells from Ischemia/Reperfusion Injury in Cirrhotic Rats. World J Gastroenterol, 13(40), 5384-5390. doi:10.3748/wjg.v13.i40.5384

Yamamoto, H., Kondo, M., Nakamori, S. N., H, Wakasa, K., Sugita, Y., Chang-de, J., Kobayashi, S., Damdinsuren, B., \& Dono, K. (2003). JTE-522, A Cyclooxygenase-2 Inhibitor, is An Effective Chemopreventive Agent Against Rat Experimental Liver Fibrosis Gastroenterology 125, 556-571. 